UDC 796.339.138

\title{
PHYSICAL AND SPORTS ENTERPRISE COMPETITIVENESS
}

\author{
Liudmyla Shuba', Victoria Shuba ${ }^{2}$ \\ ${ }^{1}$ National University Zaporizhzhia Polytechnic, Zaporizhzhia, Ukraine, mila.shuba@gmail.com \\ ${ }^{2}$ Prydniprovska State Academy of Physical Culture and Sports, Dnipro, Ukraine, shubaV14@meta.ua
}

https://doi.org/10.29038/2220-7481-2020-03-17-22

\begin{abstract}
s
Despite the external and internal aspects, Ukraine continues to develop and modernize in diverse fields of activity. One of the areas that is gaining momentum in recent years is the activities of physical culture and sports organizations and their competitions with each other. The competitiveness of sports organization is a set of qualitative (non-price) and cost characteristics of physical culture and sports organization that meet the specific needs of sports organizations customers. The Research Aimed to analyze the competitiveness of physical culture and sports organization on the basis of relevant indicators to manage the competitiveness level of sports enterprise. Research Organization. The study was conducted from October 1, 2019 till February 29, 2020 on the basis of physical culture and sports organization - sports club «Sportexpert». The analysis of the services competitiveness was carried out on the example of the sports enterprise - sports club «Sportexpert». The integral coefficient method was chosen to assess the competitiveness. Research Results. Competitiveness assessment of physical culture and sports enterprises is impossible without analysis of the services competitiveness they provide. The main advantage of the step-by-step method of competitiveness is the assessment that it involves direct measurement and evaluation of the studied indicators. Furthermore, this technique allows taking into account the significance of certain parameters with the help of weigh coefficients, which makes it possible to determine the degree of their impact on the final integrated indicator of competitiveness. The general index of service competitiveness of visiting the gym in the sports club «Sportexpert» is 0,77 . That is, $77 \%$ of sports club visitors are satisfied with the service provided. Conclusions. The obtained results of calculations demonstrate that analyzed sports club generally has good competitiveness assessment. The integral evaluation determination of competitiveness was based on 10 indicators - characteristics of the sports club activity. The strong and weak points of the «Sportexpert» sports club have been defined. The main indicators that needed to be changed were prestige of the club, cost of services, quality of equipment, professionalism of coaches, and efficiency of training programs.
\end{abstract}

Key words: competitive advantages, competitiveness, physical culture and sports organization, coefficient method, sports club.

Людмила Шуба, Вікторія Шуба. Конкурентоспроможність фізкультурно-спортивного підприємства. Незважаючи на зовнішні та внутрішні аспекти, Україна продовжує розвиватися й модернізуватись у різних сферах діяльності. Одним із таких напрямів, який останнім часом набирає обертів, є діяльність фізкультурно-спортивних організацій i їх конкуренція між собою. Конкурентоспроможність фізкультурно-спортивної організації - це сукупність якісних (нецінових) та вартісних характеристик фізкультурно-спортивної організації, які забезпечують задоволення конкретних потреб клієнтів спорторганізацій. Мета - проаналізувати конкурентоспроможності фізкультурно-спортивної організації на основі дослідження відповідних показників із метою управління рівнем конкурентоспроможності спортивного підприємства. Організація дослідження. Дослідження проводили 3 01 жовтня 2019 року до 29 лютого 2020 р. на базі фізкультурно-спортивної організації спортивний клуб «Спортексперт». Аналіз конкурентоспроможності послуг проведено на прикладі спортивного підприємства спортивний клуб «Спортексперт». Для оцінки конкурентоспроможності обрали інтегральний коефіцієнтний метод. Результати. Оцінка конкурентоспроможності підприємств фізкультурно-спортивного спрямування неможлива без здійснення аналізу конкурентоспроможності послуг, які вони надають. Основними перевагами поетапної методики оцінки конкурентоспроможності $є$ те, що вона передбачає пряме вимірювання й оцінку досліджуваних показників. Також ця методика дає змогу врахувати значимість певних параметрів за допомогою коефіцієнтів вагомості, що дає можливість визначити ступінь їх впливу на кінцевий інтегральний показник конкурентоспроможності. Загальний індекс конкурентоспроможності послуги відвідання тренажерного залу в споривному клубі «Спортексперт» становить 0,77. Тобто 77 \% відвідувачі спортивного клубу задоволені надаваною послугою. Висновки. Отримані результати розрахунків показали, що аналізований спортивний клуб у цілому має непогану оцінку конкурентоспроможності. Визначення інтегральної оцінки конкурентоспроможності відбувалося на основі 10 показників - характеристик діяльності спортивного клубу. Визначено сильні й слабкі сторони спортивного клубу «Спорексперт». Основними показниками, які потребували змін, були престиж клубу, вартість послуг, якість обладнання, професійність тренерів та ефективність тренувальних програм.

Ключові слова: конкурентні переваги, конкурентоспроможність, фізкультурно-спортивна організація, коефіцієнтний метод, спортивний клуб. 
Людмила Шуба, Виктория Шуба. Конкурентоспособность физкультурно-спортивного предприятия. Несмотря на внешние и внутренние аспекты, Украина продолжает развиваться и модернизироваться в разных сферах деятельности. Одним из таких направлений за последнее время является деятельность физкультурноспортивных организаций и их конкуренция между собой. Конкурентоспособность физкультурно-спортивной организации - это совокупность качественных (не ценовых) и ценовых характеристик физкультурноспортивной организации, которые обеспечивают потребности клиентов спортивной организации. Цель проанализировать конкурентоспособность физкультурно-спортивной организации на основе исследования определенных показателей для управления уровнем конкурентоспособности спортивной организации. Организация исследования. Исследование проводилось с 01 октября 2019 года до 29 февраля 2020 года на базе физкультурно-спортивной организации спортивный клуб «Спортэксперт». Анализ конкурентоспособности услуг было проведено на примере спортивной организации спортивный клуб «Спортэксперт». Для оценки конкурентоспособности использовали интегральный коэффициентный метод. Результаты. Оценка конкурентоспособности предприятия физкультурно-спортивного направления не возможна без анализа конкуренции услуг, которые оно предоставляет. Основным плюсом поэтапной методики конкурентоспособности является то, что она предполагает прямое измерение и оценку исследуемых показателей. Так же эта методика помогает учитывать значимость определенных параметров при помощи коэффициента значимости, что способствует определению степени влияния на конечный интегральный показатель конкурентоспособности. Общий индекс конкурентоспособности услуг посещения тренажерного зала в спортивном клубе «Спортэксперт» составляет 0,77, т.е. 77 \% посетителей спортивного клуба довольны предоставляемой услугой. Выводы. Полученные результаты показали, что анализированный спортивный клуб в общем получил хорошую оценку конкурентоспособности. Определение интегральной оценки конкурентоспособности происходило на основе 10 показателей - характеристик деятельности спортивного клуба. Определены сильные и слабые стороны спортивного клуба «Спортэксперт». Основные показатели, которые требовали изменений для престижа клуба, - стоимость услуг, качество оборудования, профессионализм тренеров и эффективность тренировочных программ.

Ключевые слова: конкурентные преимущества, конкурентоспособность, физкультурно-спортивная организация, коэффициентный метод, спортивный клуб.

Introduction. Today, there is no single classification of sports organizations in Ukraine. According to the Law of Ukraine «On Physical Culture and Sports», the following types of sports and sports organizations operating in Ukraine can be distinguished: sports clubs; children's and youth sports schools; specialized educational sport institutions; schools of higher sportsmanship; Olympic training centers; student sports centers of higher educational institutions; sports and health facilities; physical health centers; centers of physical culture and sports for the disabled; physical culture teams and etc. [2; $4 ; 7]$.

The level of competitiveness of any enterprise is an important factor influencing the efficiency and success of their activities. The period of reformation is taking place in economical development of Ukraine as well as its domestic enterprises. That is why the problem of competitiveness increasing of domestic sports organizations should be considered. The high level of physical culture enterprises competitiveness will give opportunity for the enterprises to develop this branch within the country, and also with dignity to represent Ukraine in sports competitions of various levels $[3 ; 8 ; 10]$.

The problem of low level competitiveness of physical culture and sports organizations is the lack of relevant experience in improving the quality of management. Deficit of state funding and state aid, lack of preferential system, significant tax burden on the organization of physical culture and sports have a negative impact on the level of competitiveness of domestic physical culture and sports organizations. One of the factors influencing the efficiency of physical culture and sports organizations is the level of services competitiveness they provide. Taking into account that competitiveness management is a complex system focused on solving problems such as researching consumer needs, assessing the activities of competing companies, analyzing the market and its trends, etc. $[5 ; 11]$ There is a need to study and develop the competitiveness concept of sports organization, at the state, regional and local levels. The competitiveness management of sports organizations should ensure maximum use of their capabilities and the orientation of such enterprises to meet consumer requirements $[4 ; 6 ; 9]$.

To create a system of effective management competitiveness level of physical culture and sports organization it is necessary to have a clear, scientifically sound methodologies, which should be based on the competitive strategy of such enterprises, created on the base of deep economic analysis and forecasting taking into account different behaviour patterns of the system as a single unit and its subsystems. That is why there is a need to study similar experiences of foreign countries where the field of physical culture and sports is developed at a high level, among them Australia, Canada, Great Britain, etc.,in order to form the most rational and effective approach to sports management $[1 ; 9 ; 10]$. 
The contribution to the consideration of competitiveness concept of physical culture and sports organizations was made by such scientists as O. Gh. Jankovogho [4], L. I. Prokopova, M. B. Chkhajlo [8], I. M. Stakhiv $[9 ; 10]$ and others. Analyzing the research, we can say that today competitiveness of sports organizations in Ukraine is not given enough attention. This situation is the result of crisis phenomena in the country, which focuses the attention of scientists on solving the problems of the state economy, as well as the insufficient development of physical culture and sports in Ukraine [6-8].

Analysis of literature, monographs, research, articles, etc. showed that the topic of physical culture and sports organizations competitiveness in Ukraine is not given enough attention.

Goal - analyze the competitiveness of sports organization on the base of relevant indicators study in order to manage the level of sports enterprise competitiveness.

\section{Materials and Methods of Research}

Participants: the study was performed from October 1, 2019 to February 29, 2020. on the basis of the physical culture and sports organization sports club «Sportexpert». Enterprise of physical culture and sports took part in the experiment. As a controlling sports enterprise, a relative sports club was identified, which best meets all indicators of competitiveness. The experimental enterprise introduced advanced tools to increase the level of sports organization competitiveness in order to improve the process of competitiveness management.

Organization of the Study. To analyze the competitiveness of services, it is necessary to determine the object competitiveness of which will be assessed, as well as a similar service, which will be as the basis. The analysis of the competitiveness of services was conducted through the example of the sports enterprise sports club «Sportexpert».

An integral coefficient method was chosen to assess competitiveness. Products competitiveness assessment of physical culture and sports organizations is done in the following sequence:

1. Formation of consumers requirements of the physical culture and sports organization to qualities of services in a certain kind of sport, and also determination a number of indicators which will be estimated.

2. Calculation of weigh coefficients of the selected indicators. Determination of the weigh factors of each indicator should be based on the assessment received by the indicator. Significance level of each product parameter is determined on the basis of grading on a scale from 1 to 5 , where: 5 - the most important; 4 - very important; 3 - important; 2 - not very important; 1 - does not matter at all.

3. Assessment of selected indicators of product competitiveness in their own organization as well as competitors organization.

4. Choicing «standard» as a basic sample required for comparison, as well as its parameters determination $[8 ; 11]$. As a basis for comparative assessment of competitiveness and identification of key shortcomings and indicators for improvement, we will take a standard gym that will meet the best all the indicators of competitiveness of the sports club and the consumers wishes.

5. Establishing individual indicators of product competitiveness, comparing the indicators of the analyzed organization with the competing organization, as well as the «standard» value.

6. Determination of relative indicators of competitiveness by pairwise comparison of unit indicators of the analyzed products and products of competitors (in case of comparison with competitive enterprise indicators), and by comparison of relative indicators of competitiveness with similar standard indicators (in case of comparative assessment with a standard enterprise).

7. Determination of the integral criterion of competitiveness (competitiveness index) by products.

8. Drawing conclusions from the results of the assessment [8;10].

Statistical analysis: data was performed using the program SPSS Statistica.

Research Results. Competitiveness assessment of a sports enterprise is not possible without analyzing the competitiveness of the services it provides. Thus, to determine a number of characteristics that affect the level of consumer satisfaction, 10 indicators were selected. Calculation of weigh coefficients was performed for chosen indicators. To make calculations, it was necessary to determine the ratings that characterize the level of significance of a particular indicator, the ratings were put on a scale from 1 to 5 . Determining the indicators significance for visitors of the sports club - «Sportexpert» was carried out by voting on the website of the sports club. 696 people who attend this sports club took part in the voting. As a result of the voting, each of the indicators received a certain number of votes, which had to be translated into a score. The establishment of the score was done by determining the proportion of results on the $\mathrm{i}$-th indicator, which are shown in table 1. 
Table of Competitiveness Indicators Significance

\begin{tabular}{|c|c|c|c|}
\hline Indicator & $\begin{array}{l}\text { Number } \\
\text { of Votes }\end{array}$ & Useful Ratio & Score \\
\hline Interior & 24 & 3 & 1 \\
\hline Services costs & 162 & 23 & 5 \\
\hline Quality of equipment & 96 & 14 & 3 \\
\hline Professionalism of trainers, efficiency of training programs & 142 & 20 & 4 \\
\hline Location of the club & 129 & 19 & 4 \\
\hline Level of service & 39 & 6 & 2 \\
\hline Reviews from friends & 17 & 2 & 1 \\
\hline Prestige of the club & 6 & 1 & 1 \\
\hline $\begin{array}{l}\text { Range of additional services (massage, medical office, sale of } \\
\text { sports nutrition, etc.) }\end{array}$ & 9 & 1 & 1 \\
\hline Club congestion & 72 & 10 & 2 \\
\hline Total & 696 & 100,00 & 24 \\
\hline
\end{tabular}

To assess the competitiveness of sports club services, it was necessary to determine the individual indicators of services competitiveness.

To make calculations, it was necessary to establish the degree of satisfaction with the $i$-th characteristic of the service, in points. To obtain such an assessment, there was a questionnaire evaluation of services in points on a scale from 1 to 10 , where 1 - the minimum score of satisfaction with the service, 10 - the maximum. The standard sample of the service for all indicators had a maximum score of 10 points. The results are given in table 2 .

Table 2

Assessments of Competitiveness Indicators Sports Club «Sportexpert»

\begin{tabular}{|c|l|c|c|c|}
\hline Weigh Factor & \multicolumn{1}{|c|}{ Indicator } & $\begin{array}{c}\text { Average } \\
\text { Rating }\end{array}$ & $\begin{array}{c}\text { Relative Indicator } \\
\text { of the Sports Club } \\
\text { «Sportexpert» }\end{array}$ & $\begin{array}{c}\text { I-th Indicator } \\
\text { of Competitiveness }\end{array}$ \\
\hline 0,04 & Interior & 7,75 & 0,78 & 0,03 \\
\hline 0,21 & Services costs & 7,58 & 0,76 & 0,16 \\
\hline 0,13 & Quality of equipment & 8,08 & 0,81 & 0,10 \\
\hline 0,17 & $\begin{array}{l}\text { Professionalism of trainers, efficiency } \\
\text { of training programs }\end{array}$ & 8,08 & 0,81 & 0,13 \\
\hline 0,17 & Location of the club & 7,92 & 0,79 & 0,13 \\
\hline 0,08 & Level of service & 7,92 & 0,79 & 0,07 \\
\hline 0,04 & Reviews from friends & 8,58 & 0,86 & 0,04 \\
\hline 0,04 & Prestige of the club & 7,42 & 0,74 & 0,03 \\
\hline 0,04 & $\begin{array}{l}\text { Range of additional services } \\
\text { (massage, medical office, sale } \\
\text { of sports nutrition, etc.) }\end{array}$ & 5,00 & 0,50 & 0,02 \\
\hline 0,08 & Club congestion & 7,33 & 0,73 & 0,06 \\
\hline 1,00 & \multicolumn{2}{|l}{} \\
\hline
\end{tabular}

So, the competitiveness general index of the service of visiting the gym in the sports club «Sportexpert» is 0,77 . We can make a conclusion that $77 \%$ of visitors to the sports club are satisfied with the service provided. In general, we can say that the result positively characterizes the activities of the sports club, and indicates that it is quite effective. Visitors are satisfied with the cost of the service, professionalism of the coaches, and the location of «Sportexpert». 
However, from the obtained results it is possible to define «problem indicators» of service. For example, the competitiveness index of such an indicator as the quality of training equipment is not high enough, so the company should pay attention to updating and increasing the number of sports equipment. Also, it is necessary to pay attention to such indicators as the prestige of the club, the workload of the club and the range of additional services.

Discussion. The meaning of physical culture and sports organization competitiveness can be defined as its performance result, which is the effective functioning of the enterprise and the presence of competitive advantages over similar physical culture and sports organizations, achieved by developing an effective management system, using advanced approaches in teaching and training, experience research of similar physical culture and sports organizations in foreign countries, and also by means of rational use of own possibilities and constant monitoring of competitors activity $[2 ; 3 ; 7 ; 11]$.

Providing competitive services is an integral part of the successful operation of any sports club. By increasing the competitiveness of services provided, sports organizations are able not only to maintain a position in the already gained market share, but also increase it, and also raise the cost of services by increasing their competitiveness. The growth of the services competitiveness leads to an increase in the competitiveness of sports organization. A competitive enterprise is able to expand its market share in the regional level. Thus, it is the analysis of the services competitiveness provided by the sports club «Sportexpert» occupies a significant place in the analysis of the enterprise competitiveness.

The main activity of the sports club «Sportexpert» is trainings in the gym. For the successful prosperity of the sports club it is necessary to ensure a rational selection of sports equipment, in this case, exercise machines for the gym. First of all, it is necessary to take into account the direction of their operation, because in the complex equipment should help people to work all muscle groups separately as well as simultaneously. But also important are the following indicators: interior, cost of services, professionalism of coaches and the effectiveness of training programs, the location of the club, the range of additional services (massage, medical office, sale of sports nutrition, etc.), feedback from friends and more.

As a result, to obtain an assessment of the service competitiveness, it is necessary to determine integrated indicator of the service competitiveness. The overall competitiveness index was defined as the sum of the i-th competitiveness index for each service characteristic and it is 0,77. This figure shows that $77 \%$ of visitors to the sports club are satisfied with the service provided. But there are still $33 \%$ thanks to which the club's leaders will analyze the weaknesses and find the ways to improve the club's conditions.

Conclusions. In the course of the research the analysis of the competitiveness level of the sports organization was carried out on the example of the sports club «Sportexpert» in Zaporozhye. Assessments of the competitiveness level were done by calculating the integrated competitiveness index. The basis for comparison was a conditional reference sports club, which best meets all the requirement of visitors. The obtained results of calculations showed that the analyzed sports club in general has a good assessment of competitiveness (the overall competitiveness index was 0,77). The determination of the integrated assessment of competitiveness was based on 10 indicators - the characteristics of the sports club. Thus, the strengths and weaknesses of the sports club «Sporexpert» were identified.

The main indicators that needed to be changed were the prestige of the club, the cost of services, the quality of equipment, the professionalism of coaches and the effectiveness of training programs.

\section{References}

1. Benchmarking Analysis on Sport Organizations (2014). KPMG Sport Advisory. 10 Shelley St, Sydney, Australia: KPMG Advisory Ltd., 72.

2. Derzhavna sluzhba statystyky «Ukrstat». State Statistics Service «Ukrstat». URL: http://www.ukrstat.gov.ua/

3. Fedorova, A. O. Marketynhovi kanaly komunikatsiy na rynku sportyvno-ozdorovchykh posluh. [Marketing channels of communication on the market of sports and health products. URL: http://probl-economy.kpi.ua/ $\mathrm{pdf} / 2012-22 . \mathrm{pdf}$

4. Jankovogho, O. Gh. (2013). Konkurentnospromozhnistj pidpryjemstva: ocinka rivnja ta naprjamy pidvyshhennja: [monoghrafija]. [Competitiveness of the enterprise: assessment of the level and directions of improvemen: [monograph]. Odesa: Atlant, 470.

5. Liulchak, Z. S., Hayvanovych N. V. (2014). Six sigma in the activities of the intermediary companies as a factor of improving performance. The advanced science journal. USA, 6, 65-70.

6. Obzor runka fytnes-klubov Ukraynu. Market review of fitness clubs in Ukraine. URL: http://fanat.ua/brand/ analiz/obzor_rynka_fitnes_k_80634.html

7. Pro skhvalennja Koncepciji Derzhavnoji ciljovoji socialjnoji proghramy rozvytku fizychnoji kuljtury i sportu na period do 2020 roku. [About approval of the Concept of the State target social program of physical culture 
and sports development for the period till 2020]. Kabinet Ministriv Ukrajiny. Koncepcija vid 09.12.2015 № 1320-r.

8. Prokopova, L. I., Chkhajlo, M. B. (2012). Osnovy marketynghu i menedzhmentu fizkuljturno-ozdorovchykh poslugh. [Principles of marketing and management of the health and fitness services. Teaching medium]. Navchaljnyj posibnyk. Sumy: Vyd-vo SumDPU im. A. S. Makarenka, 298.

9. Stakhiv, I. M. (2014). Zarubizhnyj poghljad na reghuljuvannja rynku sportyvno- ozdorovchykh poslugh. [Foreign view on the market regulation of sports and wellness services] Nauka j ekonomika, 35. $251-254$. http://nbuv.gov.ua/UJRN/Nie_2014_3_38

10. Stakhiv, I. M. (2017). Reghuljuvannja rynku sportyvno-ozdorovchykh poslugh: [monoghrafija]. [Regulation of the market of sports and health services: [monograph]. L.: Redakcija «UP», 200.

11. Zhdanova, O. M. Chekhovsjka, L. Ja. (2009). Upravlinnja sferoju fizychnogho vykhovannja i sportu. Navchaljnyj posibnyk. [Management of the sphere of physical education and sportsn[Scientific equipment] Droghobych: Kolo, 224.

Стаття надійшла до редакції 24.08.2020 p. 